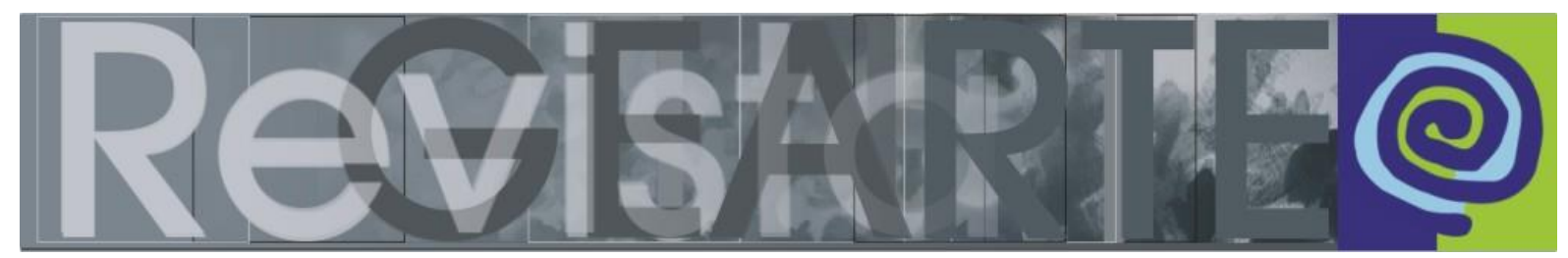

ISSN 2357-9854 | e-ISSN 2596-3198 (online)

\title{
Homenagem a Arthur Efland (1929-2020)
}

Ana Mae Barbosa

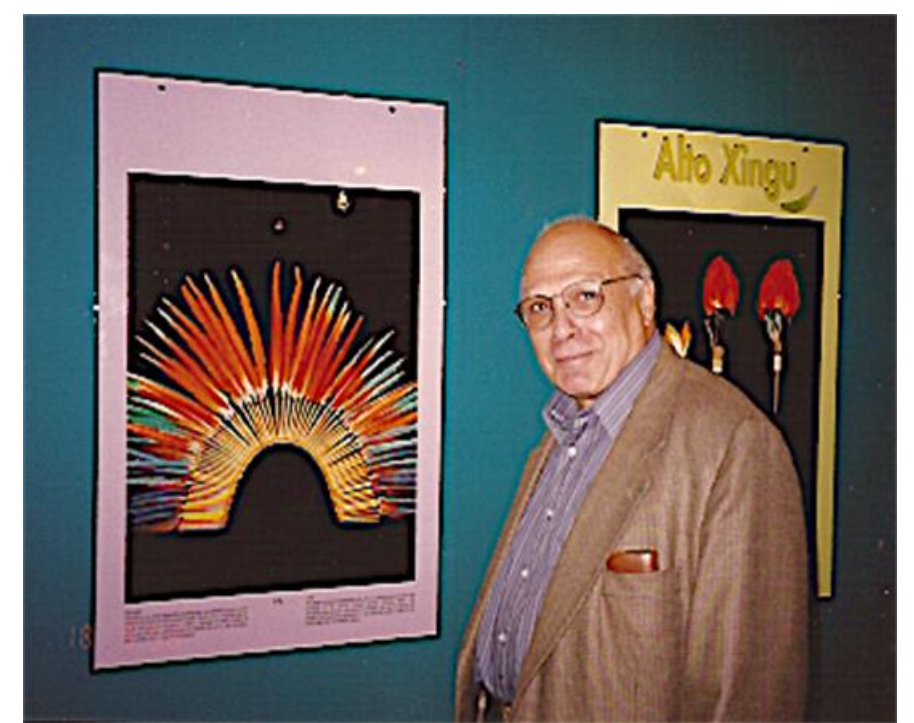

Arthur Efland em São Paulo (1998). Foto de Mary Stokrocki.

Morreu em Ohio (EUA) Arthur Efland no dia 11 de abril de 2020 com 90 anos de lucidez dedicados à Arte/Educação.

Na década de 1970 um de seus artigos sobre a arte escolar chamou a atenção para o fato de que a chamada Educação Artística nas escolas não tinha nada a ver com o mundo da arte; eram meros exercícios escolares. Sua crítica abriu espaço para o pós-modernismo em Arte/Educação, facilitando a entrada das imagens da arte nas salas de aula, do jardim da infância aos ateliês nas universidades. Antes reinava a esquizofrenia na formação dos artistas: a dicotomia entre a prática e a teoria. Nas décadas seguintes publicou muito, mas dois livros mudaram o status da arte na educação e na história de seu ensino, um sobre Arte e Cognição e outro sobre História do Ensino da Arte.

Eu era uma leitora ávida dos textos de Arthur Efland, desde que fiz meu doutorado na Universidade de Boston e me apaixonei pela História do Ensino da Arte Ele se transformou em um de meus heróis intelectuais. Naquela época, 


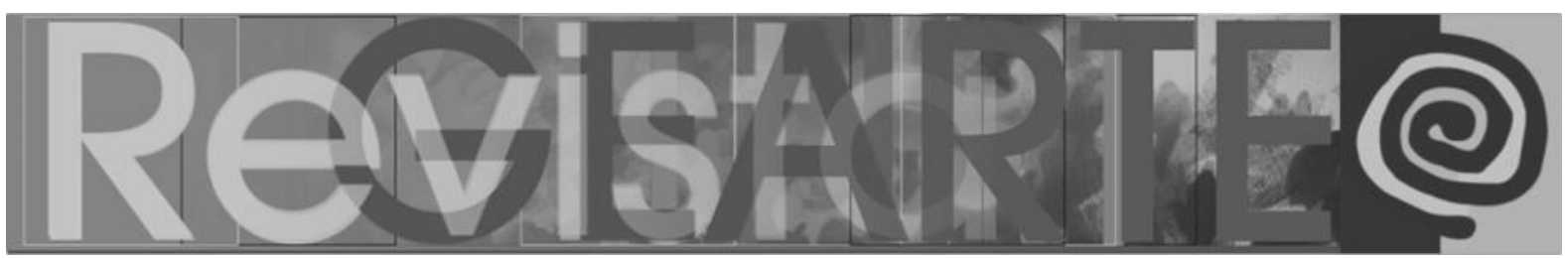

História do Ensino da Arte era um assunto relegado ao esquecimento, sem importância e quase sem público leitor. Ele deu prestígio aos estudos históricos de Art Education nos Estados Unidos. Depois, quando o conheci pessoalmente, minha admiração aumentou muito. Era um ser humano extraordinário; percebia rapidamente as qualidades das pessoas e procurava se comunicar e ressaltar essas qualidades em vez de nos classificar pelos defeitos. Era um historiador com paciência histórica em relação a seus alunos, esperava que se desenvolvessem e se precisava criticar algo o fazia de maneira suave, às vezes um pouco irônica, mas sempre dialogal.

Arthur e Jenny receberam a mim e minha família (João Alexandre e Ana Amália) como se fôssemos de sua própria família, quando por um breve período fui professora da The Ohio State University. Eles procuraram satisfazer minha sede de conhecer as instituições culturais próximas e não posso esquecer a magnifica experiência que me proporcionaram ao me levarem a ver uma exposição didática de uma obra de Frida Khalo no Museu de Arte da Universidade de Miami. Vi o que considero um milagre museográfico. Uma única obra (o autorretrato de Frida Kahlo como veado) alimentando uma exposição que capturava os sentidos e era profundamente significativa.

Se quiserem conhecer seus textos comecem com o intitulado "Cultura, Sociedade, Arte e Educação num Mundo Pós-Moderno" (em GUINSBURG, Jacó; BARBOSA, Ana Mae (Orgs.). O pós-modernismo. São Paulo: Perspectiva, 2008. p. 173-188).

Arthur Efland conquistou para a História do Ensino da Arte e do Design um lugar de respeito entre as áreas de conhecimento. Não existe conhecimento respeitável sem História. 